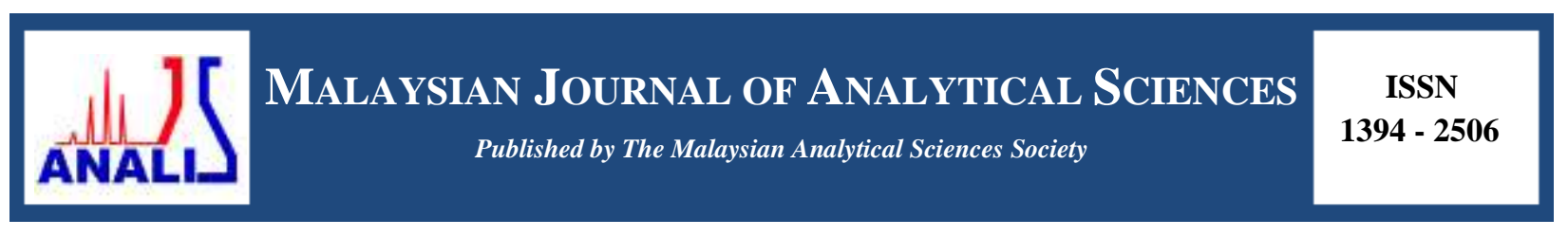

\title{
RECENT ADVANCES IN THE PREPARATION OF OIL PALM WASTE- BASED ADSORBENTS FOR REMOVAL OF ENVIRONMENTAL POLLUTANTS - A REVIEW
}

\author{
(Kemajuan Terkini dalam Penyediaan Penjerap Berasaskan Sisa Kelapa Sawit untuk \\ Penyingkiran Bahan Pencemar Alam Sekitar - Sebuah Ulasan)
}

\author{
Faridah M. Marsin ${ }^{1,2}$, Wan Aini Wan Ibrahim ${ }^{1,3}$, Hamid Rashidi Nodeh ${ }^{4}$, Zetty Azalea Sutirman ${ }^{1}$, Ng Nyuk Ting $^{1}$, \\ Mohd Marsin Sanagi ${ }^{1,3 *}$ \\ ${ }^{1}$ Department of Chemistry, Faculty of Science, \\ Universiti Teknologi Malaysia, 81310 UTM Johor Bahru, Johor, Malaysia \\ ${ }^{2}$ Malaysia Department of Chemistry (Southern Branch), 80100 Johor Bahru, Johor, Malaysia \\ ${ }^{3}$ Centre for Sustainable Nanomaterials, Ibnu Sina Institute for Scientific and Industrial Research, \\ Universiti Teknologi Malaysia, 81310 Johor Bahru, Johor, Malaysia \\ ${ }^{4}$ Department of Chemistry, Faculty of Science, \\ University of Tehran, Tehran, Iran \\ *Corresponding author: marsin@kimia.fs.utm.my
}

Received: 10 November 2017; Accepted: 28 February 2018

\begin{abstract}
The palm oil industry is an excellent source for huge quantities of highly useful biomass. Utilization of oil palm biomass-based materials for the removal of environmental pollutants appears to be a viable solution in the lights of promoting sustainable development. This article aims to review recent advances in the preparation of adsorbent from different parts of oil palm biomass for the removal of heavy metal and organic environmental pollutants from water. Physical and chemical factors that enhance the applicability of oil palm waste as adsorbents are also discussed. It is clear that each part of the oil palm biomass is potentially applicable as biosorbents for most environmental pollutants and the capability could be further enhanced through modifications in accordance with its intended pollutants. Modifications by chemical treatments such as acidic, basic or drying agent treatments under optimum dosages have been found to have significant effects on the selectivity of the analyte absorption. In general, basic treatment is more suitable for common pollutants such as metals, pesticide and basic dyes. Meanwhile, the acidic treatment is more suitable for non-polar organic pollutants such as phenols. Recent trends in the application of oil palm biomass as biosorbents are also discussed that together open new doors to sustainable development.
\end{abstract}

Keywords: oil palm biomass, adsorbent, activated carbon, environmental pollutants

\section{Abstrak}

Industri minyak kelapa sawit merupakan sumber yang baik untuk mendapatkan biojisim bermanfaat dalam kuantiti yang besar. Penggunaan bahan berasaskan biojisim minyak kelapa sawit bagi penyingkiran pencemar alam sekitar merupakan salah satu penyelesaian berdaya maju dalam mempromosi pembangunan mampan. Artikel ini bertujuan untuk mengulas kemajuan dalam penyediaan penjerap daripada pelbagai bahagian biojisim kelapa sawit bagi penyingkiran ion logam berat dan pencemar organik alam sekitar daripada air. Faktor fizikal dan kimia bagi meningkatkan kebolehgunaan sisa kelapa sawit sebagai penjerap juga dibincangkan. Ianya jelas bahawa setiap bahagian biojisim kelapa sawit berpotensi untuk digunakan sebagai bio-pengerap bagi kebanyakan bahan pencemar, dan keupayaannya dapat dipertingkatkan melalui pengubahsuaian sesuai dengan bahan pencemar yang digunakan. Pengubahsuaian dengan rawatan kimia misalnya rawatan asid, alkali dan ejen pengeringan dengan dos yang optimum didapati memberi kesan terhadap pemilihan penjerapan analit. Secara keseluruhan, rawatan alkali lebih sesuai bagi 
bahan pencemar lazim misalnya logam, racun mahluk perosak, dan pewarna alkali. Sementara itu, rawatan asid lebih sesuai untuk bahan pencemar organik yang tidak berkutub misalnya fenol. Aliran terkini dalam aplikasi biojisim kelapa sawit sebagai bio-pengerap juga dibincangkan bagi membuka laluan baharu untuk pembangunan mampan.

Kata kunci: biojisim kelapa sawit, penjerap, karbon teraktif, pencemar alam sekitar

\section{Introduction}

In recent years, increasing costs and environmental considerations have led to the use of new low-cost adsorbents derived from renewable resources. Numerous researches have expanded the idea of utilizing inexpensive adsorbents from natural materials, such as agricultural waste and minerals for removal of environmental pollutants. We have dedicated time in search towards a greener and sustainable alternative adsorbents for removal of pollutants using biomaterials such as starch [1], alginate [2], agarose [3], and chitosan [4, 5]. The booming of the Elais guineensis, or generally known as oil palm, triggered the massive increase in oil palm plantation area of more than 5.74 million hectares in Malaysia in 2016 [6]. With the rapid growth of palm oil production, the amount of waste generated also shows a corresponding increase. An approximate $85.5 \%$ of agricultural wastes in Malaysia came from palm oil plantations [7]. The oil palm biomass waste consists of mainly empty fruit bunches (EFB), shell and kernels, fronds, leaves and trunks. The huge amount of waste generated has to be utilized efficiently to promote sustainability.

Currently, various technologies have been applied to convert palm oil waste to renewable energy, value-added products and bio-based products such as pellet for feedstock, fertilizers, fillers, bioplastics and adsorbent (Figure 1). Limited work has been made to retrieve valuable components such as carotene, tocopherols and tocotrienols in residue oil from palm pressed fibers [8]. However, there have been considerable developments where oil palm waste is turned into adsorbents via activated carbon, char, ash and combination with other suitable material to enhance its ability and selectivity for adsorption. This article reviews current trends in physical and chemical preparation treatments of different parts of palm oil waste as adsorbent to maximize its potential for selective removal of assorted environmental pollutants such as dyes, pesticides, metals and other organic pollutants.

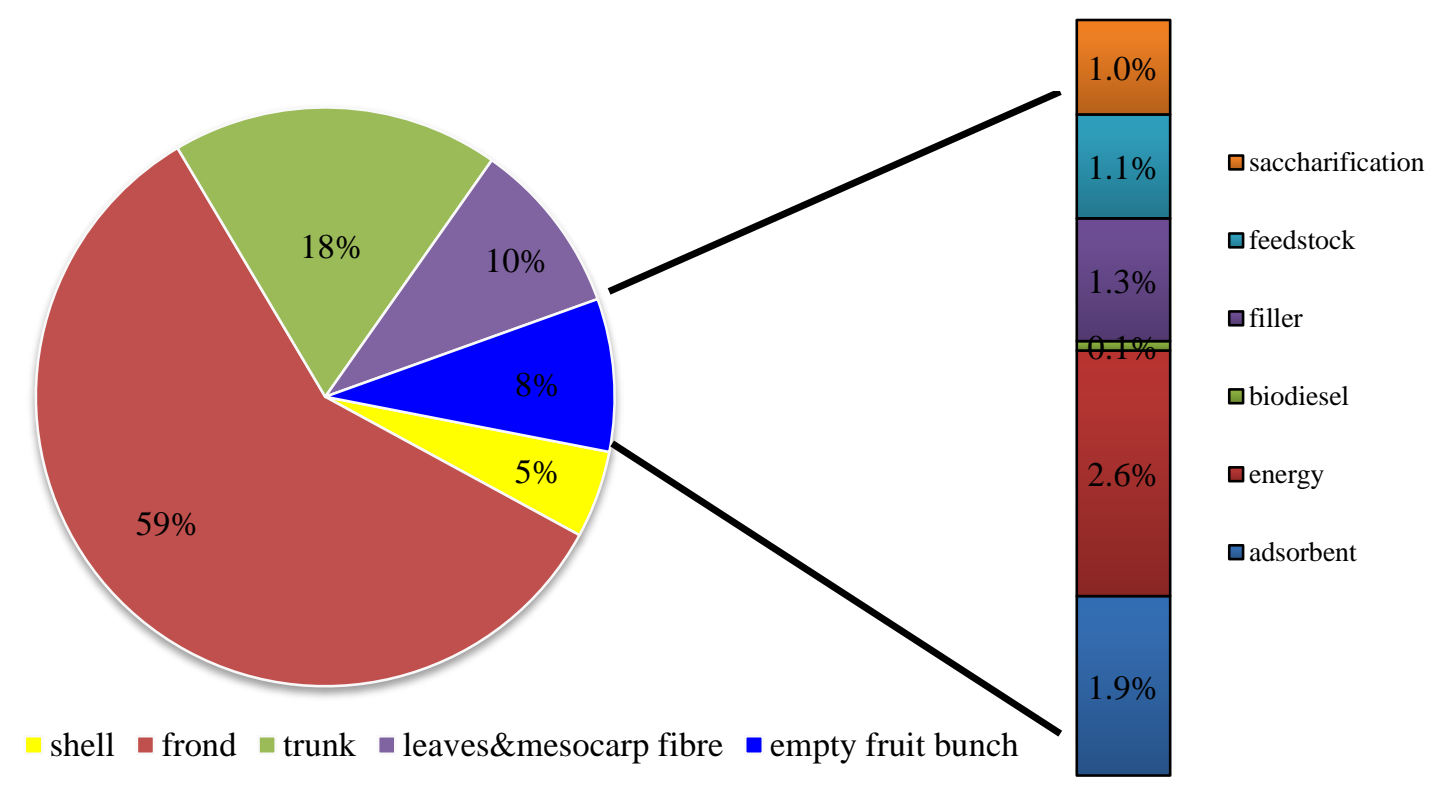

Figure 1. Oil palm biomass percentage in 2009 [9] and percentage of work towards recyclability of oil palm empty fruit bunch in recent years (2013-2016) [10] 


\section{Oil palm waste as adsorbent}

In general, oil palm mills generate a number of biomass wastes. The amount of biomass produced by an oil palm tree, inclusive of the oil and lignocellulose materials is on the average of $231.5 \mathrm{~kg}$ dry weight/year [7]. EFB and mesocarp fiber is the highest contributor of oil palm waste, with approximately 15.8 and 9.6 million tonnes, respectively [11]. EFB, mesocarp fiber and shells are collected during the pressing of sterilized fruits whilst oil palm fronds are available daily throughout the year when the palms are pruned during the harvesting of fresh fruit bunch for the production of oil. Oil palm trunk is obtained during the replantation of the oil palm trees that occurred every 15-20 years. Recent research output proved that each part of oil palm waste could be converted into value added products such as oil palm activated carbon that has been used to treat air toxics such as carbon monoxide $(\mathrm{CO})$ and sulphur oxides $\left(\mathrm{SO}_{\mathrm{x}}\right)[12,13]$.

The adsorbent obtained from different parts of oil palm biomass show different morphology in accordance to its composition (Table 1) as it was turned to activated carbon for the enhancement of adsorption process. Biomass with higher cellulose composition will produce low molecular weight products comprising anhydro-sugar, aldehyde, hydroxyl, furan, acetic acid and the carbonaceous chars. On the other hand, when lignin decomposes under elevated temperature, unsaturated chain and phenolic compounds with higher molecular weight, such as eugenol, styrene, alcohols, and carbonaceous chars will be produced [14]. This occurrence will in turn have an effect on selectivity of the analytes towards the carbon produced.

Table 1: Basic composition percentage of oil palm waste

\begin{tabular}{lcccccc}
\hline Oil Palm Waste & $\begin{array}{c}\text { Cellulose } \\
(\boldsymbol{\%})\end{array}$ & $\begin{array}{c}\text { Hemicellulose } \\
(\boldsymbol{\%})\end{array}$ & $\begin{array}{c}\text { Lignin } \\
(\boldsymbol{\%})\end{array}$ & $\begin{array}{c}\text { Inorganic } \\
\text { Compounds } \\
(\boldsymbol{\%})\end{array}$ & $\begin{array}{c}\text { Waste Percentage } \\
\text { Generated from Palm } \\
\text { Oil Industry (\%) }\end{array}$ & References \\
\hline Empty fruit bunch & 25 & 28 & 27 & 16 & 22 & {$[15]$} \\
Frond & 35 & 36 & 29 & n.a. & 14 & {$[16]$} \\
Shell & 28 & 22 & 44 & n.a. & 5 & {$[17]$} \\
Trunk & 50 & 70 & 20 & n.a. & n.a. & {$[18]$} \\
$\begin{array}{l}\text { Leaves/mesocarp } \\
\text { fiber }\end{array}$ & 45 & 48 & 27 & n.a. & n.a. & {$[19]$} \\
\hline
\end{tabular}

* n.a. - not available

The adsorption characteristics of activated carbons are generally governed by the surface area pores formation on the surface, and surface functional groups. It is believed that mesopores are more suitable for adsorption as compared to micropores and macropores [18]. Surface functional groups play an important role during cationic and anionic adsorbate removal. Thus the specific treatment of each part of oil palm waste is a crucial step in the advancement of oil palm waste based adsorbent.

The difference in thermal treatment gave a significant impact on the textural properties of the oil palm-based adsorbent. This was proven by Hamza et al. [20] who reported that the pore networks in oil palm shell increased with increase of up to $700{ }^{\circ} \mathrm{C}$. Nomanbhay et al. [15] found that microwave assisted extraction followed by basic treatment of oil palm EFB significantly improved the saccarification of EFB by removing more lignin and hemicellulose, and increasing the accessibility to hydrolytic enzymes. Furthermore, a recent study also concluded that the increment of activation temperature on oil palm empty fruit bunch will noticeable decrease the pore size, increase the surface area and the amount of carbonyl groups, thus increasing the probability of phenolic analyte adsorption [21].

The use of dehydrating agent can be categorized into either acid or basic treatment, whereby both treatments are efficient methods used to produce adsorbents with high surface area and porosity. Wirasnita et al. [22] found that 
the evaporation of the chemicals impregnated on the surface of the precursor-EFB, formed smaller cavities during activation process, and at the same time restricts the formation of tar.

Other impregnation treatments such as chitosan coating-oil palm waste - based adsorbent was also studied to improve the structure and surface area of the adsorbent [23]. The coating was found to increase its hydroxyl groups for more adsorption of polar pollutants. Such treatment onto different parts of oil palm waste to develop suitable adsorbent was discussed in accordance to the type of pollutants generally common in water matrices.

\section{Removal of dyes using oil palm adsorbents}

Dyes are a major source of pollution that is generally present in effluents from textile industries. These dye effluents are considered toxic as they reduce photosynthetic activity due to the coloration of water, and in turn affects the symbiotic process in the aqueous system. Palm oil mill effluents derived from bleaching process can cause coloration of streams. Thus, adsorption studies have been carried out using oil palm biomass-based adsorbents for the removal of dyes in streams.

The procedure of turning waste into adsorbents generally requires physical treatment. This was evident from recent studies on the removal of dyes (Table 2). Hameed et al. [24] postulated that pyrolysis at an optimum temperature of $862{ }^{\circ} \mathrm{C}$ can change the characteristics of oil palm EFB-based carbon for maximum removal of targeted dye, methylene blue. They also applied the same procedure to prepare adsorbent from oil palm trunks without treatment and found high malachite green uptake of $149.35 \mathrm{mg} / \mathrm{g}$ [25]. Meanwhile, Montoya-Suarez et al. [26] studied the physical treatment of oil palm shell at $600-800^{\circ} \mathrm{C}$ and obtained adsorbent with high surface area of $1268 \mathrm{~m}^{2} / \mathrm{g}$.

Sajab et al. used oil palm EFB for the removal of anionic and cationic dyes [27]. They noticed changes in selectivity when using different types of treatments. The EFB-citric acid treated is more selective towards targeted cationic dye (methylene blue) with an uptake of $450.4 \mathrm{mg} / \mathrm{g}$ of adsorbent, whilst EFB-polyethylene imine has higher tendency to adsorb the targeted anionic dye (phenyl red) with $555.4 \mathrm{mg} / \mathrm{g}$ [28]. When combined in a continuous column bed, EFB-polyethylene imine was more dominant compared to EFB-citric acid, which influenced the simultaneous adsorption of methylene blue and phenyl red.

The ability of oil palm fiber-based adsorbent was investigated by Kietkwanboot [29] for the decolorization of highly alkaline palm oil mill effluent (POME). With the combination of oil palm fibers and Trameters hirsuta AK4 microorganism embedded onto the fiber, up to $82.4 \%$ POME decolorization was achieved. Meanwhile, Hussin et al. [30] successfully treated oil palm fronds with mixtures of acid and basic treatment to extract microcrystalline cellulose and tested the adsorption of methylene blue with a mild uptake of $51.81 \mathrm{mg} / \mathrm{g}$.

The oil palm ash from oil palm waste was tested for its adsorption ability by Khanday et al. [25]. To compensate for the loss of lignocellulose in oil palm ash, it was added with chitosan and treated using sodium hydroxide for the removal of methylene blue and acid blue 29 dyes. They noticed that both acid blue 29 and methylene blue were able to be absorbed by the oil palm ash-chitosan adsorbent with and uptake of $270 \mathrm{mg} / \mathrm{g}$ and $199.2 \mathrm{mg} / \mathrm{g}$, respectively. This was due to the presence of more anionic sites from the oil palm ash and cationic sites from amino and hydroxyl groups from chitosan.

Wong et al. took it one step further by using oil palm shell activated carbon with the addition of magnetic nanoparticles for easier separation of adsorbents from water samples [31]. They tested and found that it has the ability to adsorb methylene blue with a good uptake of $163.3 \mathrm{mg} / \mathrm{g}$ due to hydrophobic interactions between oil palm shell and analytes, and the presence of magnetite that contributes via ionic interaction between metal and analytes. 
Table 2. Literature studies on preparation of oil palm waste-based adsorbent for removal of dyes

\begin{tabular}{|c|c|c|c|c|c|}
\hline $\begin{array}{l}\text { Oil Palm } \\
\text { Waste Part }\end{array}$ & $\begin{array}{l}\text { Activation } \\
\text { Temperature }\end{array}$ & Treatment & Dyes & $\begin{array}{c}\text { Removal } \\
\text { Percentage / } \\
\text { Uptake }\end{array}$ & Ref. \\
\hline \multirow[t]{2}{*}{ Oil palm EFB } & $862^{\circ} \mathrm{C}$ & Potassium hydroxide & Methylene blue & $400 \mathrm{mg} / \mathrm{g}$ & [24] \\
\hline & $120^{\circ} \mathrm{C}$ & $\begin{array}{l}\text { Citric acid and polyethylene } \\
\text { imine }\end{array}$ & $\begin{array}{l}\text { Methylene blue and } \\
\text { phenyl red }\end{array}$ & $\begin{array}{c}130 \mathrm{mg} / \mathrm{g} \text { and } \\
170 \mathrm{mg} / \mathrm{g}\end{array}$ & [28] \\
\hline Oil palm fibers & Nil & Trameters hirsuta fungus & $\begin{array}{l}\text { Decolorization } \\
\text { POME* }\end{array}$ & $82.4 \%$ & [29] \\
\hline $\begin{array}{l}\text { Oil palm } \\
\text { fronds }\end{array}$ & $\begin{array}{l}\text { Room } \\
\text { temperature }\end{array}$ & $\begin{array}{l}\text { Acetic acid and sodium } \\
\text { hypochlorite, followed by } \\
\text { sodium hydroxide }\end{array}$ & Methylene blue & $51.81 \mathrm{mg} / \mathrm{g}$ & [30] \\
\hline $\begin{array}{l}\text { Oil palm } \\
\text { fronds and } \\
\text { leaves }\end{array}$ & $80-100^{\circ} \mathrm{C}$ & Nil & Methylene blue & $88.72 \%$ & {$[32]$} \\
\hline $\begin{array}{l}\text { Oil palm } \\
\text { trunks }\end{array}$ & Nil & Nil. & Malachite green & $149.35 \mathrm{mg} / \mathrm{g}$ & [25] \\
\hline \multirow[t]{2}{*}{ Oil palm shell } & Microwave & Zinc chloride & Methylene blue & $0.73 \mathrm{mg} / \mathrm{g}$ & [33] \\
\hline & $600-800^{\circ} \mathrm{C}$ & $\begin{array}{l}\text { Nil } \\
\text { Magnetic nanoparticle }\end{array}$ & $\begin{array}{l}\text { Methylene blue } \\
\text { Methylene blue }\end{array}$ & $\begin{array}{c}110 \mathrm{mg} / \mathrm{g} \\
163.3 \mathrm{mg} / \mathrm{g}\end{array}$ & $\begin{array}{l}{[26]} \\
{[31]}\end{array}$ \\
\hline \multirow[t]{2}{*}{ Oil palm ash } & Nil & Nil & Bleaching palm oil & $97.3 \%$ & [34] \\
\hline & Nil & $\begin{array}{l}\text { Sodium hydroxide and } \\
\text { chitosan addition }\end{array}$ & $\begin{array}{l}\text { Methylene blue and } \\
\text { acid blue } 29\end{array}$ & $\begin{array}{c}192.2 \mathrm{mg} / \mathrm{g} \text { and } \\
270.3 \mathrm{mg} / \mathrm{g}\end{array}$ & {$[35]$} \\
\hline
\end{tabular}

POME - palm oil mill effluent, Nil - no treatment reported.

\section{Removal of pesticides using oil palm adsorbents}

Pesticides are one of the sought-after environmental pollutants for their carcinogenic effects and accumulation into aquatic life that will cause dire effects to human health. The chosen oil palm waste-biosorbents need to have the chemical affinity towards these polar pesticides for successful adsorption.

Oil palm EFB-based adsorbent was chemically treated with basic solution of ammonia solution for the removal of 2,4,6-trichlorophenol with an impressive uptake of $168.89 \mathrm{mg} / \mathrm{g}$ [36]. Salman et al. [37] used similar KOH treatment on oil palm fronds for successful removal of bentazon. Oil palm shell treated with $\mathrm{NaOH}$ reported by Hamad et al. [38] gave a maximum uptake of $454.5 \mathrm{mg} / \mathrm{g}$ of 4-chloroguiacol. Hamad et al. [39] also found that with the use of $\mathrm{K}_{2} \mathrm{CO}_{3}$ as activating agent, the oil palm shell based adsorbent is able to successfully remove 2,4dichlorophenol with an uptake of $323.62 \mathrm{mg} / \mathrm{g}$. The use of alkaline treatment was found to effectively remove the hemicellulose part of oil palm EFB [40], leaving the lignin and cellulose part as an active adsorption sites.

Yavari et al. [41] worked on oil palm EFB using low temperature pyrolysis at $300-700{ }^{\circ} \mathrm{C}$ for the synthesis of biosorbents for the removal of imazapyr and imazapic herbicides and concluded that the reduction of pyrolysis temperature increased the adsorption of polar analytes. Similar results were reported by Salman et al. [42] who prepared oil palm fronds-based adsorbents using pyrolysis and used it for the removal of glyphosate with an uptake of $104.2 \mathrm{mg} / \mathrm{g}$. Beforehand, most of the studies used a temperature of above $800^{\circ} \mathrm{C}$ for the preparation of the adsorbent [43, 44]. Tan et al. [45] described an ineffective adsorption using oil palm shell-based adsorbent that was treated with a solution of $\mathrm{HNO}_{3}$ for atrazine removal with uptake of a mere $0.046 \mathrm{mg} / \mathrm{g}$. This showed that basic treatment is preferred for the adsorption of pesticides, as it provided basic sites for the adsorption of pesticides to occur. The maximum uptake levels of various pesticides using oil palm biomass-based adsorbents are listed in Table 3. 
Table 3. Literature studies on preparation of oil palm waste-based adsorbents for removal of pesticides

\begin{tabular}{lcllcc}
\hline $\begin{array}{l}\text { Oil Palm } \\
\text { Waste Part }\end{array}$ & $\begin{array}{c}\text { Activation } \\
\text { Temperature }\end{array}$ & Treatment & Pesticides & $\begin{array}{c}\text { Removal } \\
\text { Percentage / Uptake }\end{array}$ & Ref. \\
\hline Oil palm EFB & $814{ }^{\circ} \mathrm{C}$ & $\begin{array}{l}\text { Potassium } \\
\text { hydroxide }\end{array}$ & $2,4,6$-tricholorophenol & $168.89 \mathrm{mg} / \mathrm{g}$ & {$[43]$} \\
& $814{ }^{\circ} \mathrm{C}$ & Ammonia & 2,4-dichlorophenol & $285.71 \mathrm{mg} / \mathrm{g}$ & {$[36]$} \\
& $300-700{ }^{\circ} \mathrm{C}$ & Nil & Imazapyr, imazapic & $24 \mathrm{mg} / \mathrm{kg}$ & {$[41]$} \\
Oil palm fronds & $850{ }^{\circ} \mathrm{C}$ & $\begin{array}{l}\text { Potassium } \\
\text { hydroxide }\end{array}$ & Bentazon & $99.85 \%$ & {$[37]$} \\
& $700{ }^{\circ} \mathrm{C}$ & $\begin{array}{l}\text { Potassium } \\
\text { hydroxide }\end{array}$ & $\begin{array}{l}\text { Dichlorophenoxy } \\
\text { acetic acid }\end{array}$ & $353 \mathrm{mg} / \mathrm{g}$ & {$[44]$} \\
& $700{ }^{\circ} \mathrm{C}$ & $\begin{array}{l}\text { Potassium } \\
\text { hydroxide }\end{array}$ & Glyphosate & $104.2 \mathrm{mg} / \mathrm{g}$ & {$[42]$} \\
& $800{ }^{\circ} \mathrm{C}$ & $\begin{array}{l}\text { Sodium } \\
\text { hydroxide }\end{array}$ & 4-chloroguiacal & $454.5 \mathrm{mg} / \mathrm{g}$ & {$[38]$} \\
& & Nitric acid & Atrazine & $0.046 \mathrm{mg} / \mathrm{g}$ & {$[45]$} \\
\hline
\end{tabular}

\section{Removal of metal using oil palm adsorbents}

Metal pollution is one of the most important environmental concerns due to their toxicity and accumulation in the food chain. Wastewaters from various industries such as mining, metallurgical and electronics may contain one or more toxic metals. Oil palm biomass waste has been investigated for the removal of diverse metals from water. Salamantinia et al. [46] investigated copper and zinc uptake using oil palm fronds-based adsorbents. Oil palm EFBbased biosorbents were thoroughly investigated by Wahi et al. [47]. They used chemical treatment with $\mathrm{NaOH}$ at activation temperature of $400-700{ }^{\circ} \mathrm{C}$ to prepare the adsorbent. The removal uptake for copper, lead and mercury were at a high of $52.5 \mathrm{mg} / \mathrm{g}$. Meanwhile, Montoya-Suarez et al. [26] found that adsorbent obtained from pyrolysis of oil palm shell at $600-800{ }^{\circ} \mathrm{C}$ was able to remove only $0.37 \mathrm{mg} / \mathrm{g}$ of chromium ions. Similar findings were reported by Rehman et al. [48] who studied oil palm clinker sand as adsorbents and obtained an arsenic uptake of $9 \mathrm{mg} / \mathrm{g}$. However, a recent work by Daneshfozoun et al. [49] who used grinded oil palm EFB without any treatment for removal of lead in water and found that the lead uptake is at par with alkaline-treated based adsorbent with an uptake of $47.49 \mathrm{mg} / \mathrm{g}$. It was observed that the metal ion adsorption occurs onto the lignocellulose sites in the adsorbent. With pyrolysis, the disappearances of cellulose sites decrease the uptake of metals onto the adsorbent.

Table 4. Literature studies on preparation of oil palm waste-based adsorbent for removal of heavy metal

\begin{tabular}{lcllcc}
\hline $\begin{array}{l}\text { Oil Palm Waste } \\
\text { Parts }\end{array}$ & $\begin{array}{c}\text { Activation } \\
\text { Temperature }\end{array}$ & Treatment & Metal Ions & $\begin{array}{c}\text { Removal Percentage / } \\
\text { Uptake }\end{array}$ & Ref. \\
\hline Oil palm EFB & $400-700^{\circ} \mathrm{C}$ & Sodium hydroxide & $\mathrm{Cu}, \mathrm{Pb}, \mathrm{Hg}$ & $52.5 \mathrm{mg} / \mathrm{g}$ & {$[47]$} \\
& $\mathrm{Nil}$ & Grinded & $\mathrm{Pb}$ & $47.49 \mathrm{mg} / \mathrm{g}$ & {$[49]$} \\
& $\mathrm{Nil}$ & Magnetic nanoparticle & $\mathrm{Pb}$ & $93.7 \%$ & {$[50]$} \\
Oil palm fronds & $70^{\circ} \mathrm{C}$ & Sodium hydroxide & $\mathrm{Zn}, \mathrm{Cu}$ & $90 \%$ & {$[46]$} \\
Oil palm shell & $600-800^{\circ} \mathrm{C}$ & Nil & $\mathrm{Cr}$ & $0.37 \mathrm{mg} / \mathrm{g}$ & {$[26]$} \\
Oil palm ash & $\mathrm{Nil}$ & $\mathrm{Nil}$ & $\mathrm{As}$ & $9 \mathrm{mg} / \mathrm{g}$ & {$[48]$} \\
\hline
\end{tabular}




\section{Removal of phenolic compounds using oil palm adsorbents}

Oil palm waste-based adsorbents have also been applied in the removal of other phenolic compounds (Table 5). Lua and Jia [51] used oil palm shell treated at steam activation temperature of $675{ }^{\circ} \mathrm{C}$ to produce the adsorbents for phenol removal. They reported a successful removal of phenol with an uptake of $166 \mathrm{mg} / \mathrm{g}$. Alam et al. [52] also used steam activation for the preparation of oil palm EFB-based adsorbent obtained at a temperature of $800{ }^{\circ} \mathrm{C}$ with an uptake of $300 \mathrm{mg} / \mathrm{L}$ water. This indicates that the uptake of phenolic compounds increases with higher activation temperature. Al-Aoh et al. [53] examined oil palm ash that has been treated with acid and found that the uptake of 4-nitrophenol was high $(1000 \mathrm{mg} / \mathrm{g})$. Hamad et al. [38, 39] reported the removal of chlorinated phenolic compounds using oil palm shell activated at a high temperature of $800{ }^{\circ} \mathrm{C}$ with potassium carbonate treatment to attract the anion site of the analyte. Thus, it is apparent that high activation temperature serves as the main factor in increasing the phenolic compound adsorption capacity. Elevated activation temperatures and further acidic treatment tend to decrease the amount of oxygen groups from cellulose, thus helping in the formation of more nonpolar sites on the adsorbent that in turn increases the adsorption ability of the adsorbent towards organic pollutants.

Table 5. Literature studies on preparation of oil palm waste-based adsorbent for removal of phenol

\begin{tabular}{lcllcc}
\hline $\begin{array}{l}\text { Oil Palm } \\
\text { Waste Parts }\end{array}$ & $\begin{array}{c}\text { Activation } \\
\text { Temperature }\end{array}$ & Treatment & Analyte & $\begin{array}{c}\text { Removal Percentage / } \\
\text { Uptake }\end{array}$ & Ref. \\
\hline Oil palm EFB & $800{ }^{\circ} \mathrm{C}$ & Nil & Phenol & $200-300 \mathrm{mg} / \mathrm{L}$ & {$[52]$} \\
Oil palm shell & Steam $675{ }^{\circ} \mathrm{C}$ & Nil & Phenol & $166 \mathrm{mg} / \mathrm{g}$ & {$[51]$} \\
& $800{ }^{\circ} \mathrm{C}$ & $\begin{array}{l}\text { Potassium } \\
\text { carbonate }\end{array}$ & $\begin{array}{l}\text { 4-Cl-2- } \\
\text { methyoxyphenol }\end{array}$ & $323.62 \mathrm{mg} / \mathrm{g}$ & {$[39]$} \\
Oil palm ash & Nil & Sulfuric acid & 4-nitrophenol & $1000 \mathrm{mg} / \mathrm{g}$ & {$[53]$} \\
\hline
\end{tabular}

* nil - no further treatment

\section{Conclusion}

To uphold sustainability in the expanding palm oil industry, oil palm waste was proven a viable alternative source of adsorbent for various types of pollutants. Surface modification by physicochemical methods directs an alternative approach for the improvement of each oil palm waste-based adsorbents towards the pollutant uptake from aqueous solution. Therefore, the technique of choice could be attuned in accordance to the analytes of interest. It was also observed that for different part of oil palm waste, different activation treatment is needed for optimum removal of targeted pollutants. In general, physical activation at high temperatures was needed for all parts of oil palm biowaste for the adsorption of organic pollutants as more covalent and hydrophobic interactions may occur on the surface of the activated carbon. Chemical treatment of the adsorbent is to improve the selectivity of the adsorbent towards the analyte. Basic treatment is more suitable for anionic dyes such as acid blue 29 and phenyl red compared to cationic dyes. The addition of dehydrating agents such as zinc chloride affects the physical type of pore produced on the adsorbent.

Most of the studies reported on the removal of pesticides utilized basic treatment (ammonia, potassium hydroxide and sodium hydroxide) for enhanced chemisorption of the pesticides onto the oil palm waste-based adsorbents. The use of acid treatment reduces the uptake of pesticides, as they are repelled from the active sites of the adsorbent. It is noteworthy that adsorbents obtained from oil palm waste via basic treatment are favorable for the removal of metal ions. This preparation technique generates more hydroxyl active sites on the surface of the oil palm waste-based adsorbents for more efficient removal of metal ions. The trends also show that most organic pollutants studied favor adsorbent prepared using acid treatment and higher temperature. This is because less oxygenated active sites are produced, thus more non-polar interactions occur, increasing the uptake of organic pollutants such as phenols and glyphosate. Despite numerous works on oil palm waste-based adsorbents, there seem to be the lacking of studies on the addition and combination of other compounds with oil palm waste-based adsorbents in pursue of improved adsorbents. Thus, there is ample opportunity for future investigations such as combining palm oil waste-based adsorbents with compounds such as molecular orbital framework compounds or polymers. Such innovations might 
increase the chances of these low-cost adsorbents to be used as greener and more sustainable alternatives to more conventional adsorbents.

\section{Acknowledgement}

The authors acknowledge the Organization Prohibition of Chemical Weapon Research Grants R.J130000.7309.4B222 and R.J130000.7836.4B219 for financial supports. Faridah M.M. is a recipient of HLP scholarship under Public Service Department, Malaysia. The authors declared no conflict of interest.

\section{References}

1. Umar, A., Sanagi, M. M., Salisu, A., Wan Ibrahim, W. A., Abd Karim, K. J. and Abdul Keyon, A. S. (2016). Preparation and characterization of starch grafted with methacrylamide using ammonium persulphate initiator. Materials Letters, 185:173-176.

2. Salisu, A., Sanagi, M. M., Naim, A. A. and Karim, K. J. (2015). Removal of methylene blue dye from aqueous solution using alginate grafted polyacrylonitrile beads. Der Pharma Chemica, 7(2): 237-242.

3. Sanagi, M. M., Muzakkir Mat Jais, M. N., Kamaruzaman, S., Wan Ibrahim, W. A. and Baig, U. (2015). Multiwalled carbon nanotubes-agarose gel micro-solid phase extraction for the determination of triazine herbicides in water samples. Analytical Methods, 7(6): 2862-2868.

4. Umar, A., Abu Naim, A. and Sanagi, M. M. (2014). Synthesis and characterization of chitosan grafted with polystyrene using ammonium persulfate initiator. Materials Letters, 124: 12-14.

5. Sutirman, Z. A., Sanagi, M. M., Abd Karim, K. J. and Wan Ibrahim, W. A. (2016). Preparation of methacrylamide-functionalized crosslinked chitosan by free radical polymerization for the removal of lead ions. Carbohydrate Polymers, 151: 1091-1099.

6. Malaysia Palm Oil Board. (2016). Overview of the malaysian oil palm industry. http://bepi.mpob.gov.my/ images/overview/Overview_of_Industry_2016.pdf [Accessed online May 2017].

7. Sumathi, S., Chai, S. P. and Mohamed, A. R. (2008). Utilization of oil palm as a source of renewable energy in Malaysia. Renewable and Sustainable Energy Reviews, 12(9): 2404-2421.

8. Sanagi, M. M., See, H. H., Wan Ibrahim, W. A. and Naim, A. A. (2005). Determination of carotene, tocopherols and tocotrienols in residue oil from palm pressed fiber using pressurized liquid extraction-normal phase liquid chromatography. Analytica Chimica Acta, 538(1-2): 71-76.

9. Ng, F. Y., Yew, F. K. and Basiron, K. Y. (2011). A renewable future driven with malaysian palm oil-based green technology. Journal of Oil Palm and The Environment, 2: 1-7.

10. Web of Science Core Collection (2017). Oil palm biowaste. https://apps.webofknowledge.com, [Access online 7 November 2017].

11. Malaysian Palm Oil Board (2016). Oil palm statistics. fact sheets on malaysian palm oil. http://bepi.mpob.gov.my/images/overview/Overview_of_Industry_2016.pdf [Access online May 2017].

12. Guo, J. and Lua, A. C. (2002). Characterization of adsorbent prepared from oil-palm shell by $\mathrm{CO}_{2}$ activation for removal of gaseous pollutants. Materials Letters, 55(5): 334-339.

13. Guo, J., Xu, W. S., Chen, Y. L. and Lua, A. C. (2005). Adsorption of $\mathrm{NH}_{3}$ onto activated carbon prepared from palm shells impregnated with $\mathrm{H}_{2} \mathrm{SO}_{4}$. Journal of Colloid and Interface Science, 281(2): 285-290.

14. Meier, D., Andersons, B., Irbe, I., Chirkova, J. and Faix, O. (2008). Preliminary study on fungicide and sorption effects of fast pyrolysis liquids used as wood preservative. In A. V. Bridgwater (Ed.), Progress in Thermochemical Biomass Conversion. Oxford: Blackwell Science: 1550-1563.

15. Nomanbhay, S. M., Hussain, R. and Palanisamy, K. (2013). Microwave-Assisted alkaline pretreatment and microwave assisted enzymatic saccharification of oil palm empty fruit bunch fiber for enhanced fermentable sugar yield. Journal of Sustainable Bioenergy Systems, 3(1): 7-17.

16. Ofori-Boateng, C. and Lee, K. T. (2013). Sustainable utilization of oil palm wastes for bioactive phytochemicals for the benefit of the oil palm and nutraceutical industries. Phytochemistry Reviews, 12(1): 173-190.

17. Rugayah, A. F., Astimar, A. A. and Norzita, N. (2014). Preparation and characterisation of activated carbon from palm kernel shell by physical activation with steam. Journal of Oil Palm Research, 26(3): 251-264.

18. Ahmad, T., Danish, M., Rafatullah, M., Ghazali, A., Sulaiman, O., Hashim, R., and Ibrahim, M. N. M. (2012). The use of date palm as a potential adsorbent for wastewater treatment: A review. Environmental Science and Pollution Research, 19(5): 1464-1484. 
19. Sidik, S. M., Jalil, A. A., Triwahyono, S., Adam, S. H., Satar, M. A. H. and Hameed, B. H. (2012). Modified oil palm leaves adsorbent with enhanced hydrophobicity for crude oil removal. Chemical Engineering Journal, 203: 9-18.

20. Hamza, U. D., Nasri, N. S., Amin, N. S., Mohammed, J. and Zain, H. M. (2016). Characteristics of oil palm shell biochar and activated carbon prepared at different carbonization times. Desalination and Water Treatment, 15(17): 7999-8006.

21. Sutrisno, B. and Hidayat, A. (2015). The effects of activation temperature on physico-chemical characteristics of activated carbons derived from biomass wastes. AIP Conference Proceedings, 1699: 060016.

22. Wirasnita, R., Hadibarata, T., Mohd Yusoff, A. R. and Mat Lazim, Z. (2015). Preparation and characterization of activated carbon from oil palm empty fruit bunch wastes using zinc chloride. Jurnal Teknologi, 74(11): 77-81.

23. Nomanbhay, S. M. and Palanisamy, K. (2005). Removal of heavy metal from industrial wastewater using chitosan coated oil palm shell charcoal. Electronic Journal of Biotechnology, 8(1): 43-53.

24. Hameed, B. H., Tan, I. A. W. and Ahmad, A. L. (2008). Optimization of basic dye removal by oil palm fibrebased activated carbon using response surface methodology. Journal of Hazardous Materials, 158: 324-332.

25. Hameed, B. H. and El-Khaiary, M. I. (2008). Batch removal of malachite green from aqueous solutions by adsorption on oil palm trunk fibre: Equilibrium isotherms and kinetic studies. Journal of Hazardous Materials, 154(1-3): 237-244.

26. Montoya-Suarez, S., Colpas-Castillo, F., Meza-Fuentes, E., Rodríguez-Ruiz, J. and Fernandez-Maestre, R. (2016). Activated carbons from waste of oil-palm kernel shells, sawdust and tannery leather scraps and application to chromium(VI), phenol, and methylene blue dye adsorption. Water Science and Technology, 73(1): 21-27.

27. Sajab, M. S., Chia, C. H., Zakaria, S. and Sillanpää, M. (2015). Fixed-bed column studies for the removal of cationic and anionic dyes by chemically modified oil palm empty fruit bunch fibers : Single- and multi-solute systems. Desalination and Water Treatment, 55(5): 1372-1379.

28. Sajab, M. S., Chia, C. H., Zakaria, S. and Khiew, P. S. (2013). Cationic and anionic modifications of oil palm empty fruit bunch fibers for the removal of dyes from aqueous solutions. Bioresource Technology, 128: 571-577.

29. Kietkwanboot, A., Tran, H. T. M. and Suttinun, O. (2015). Simultaneous dephenolization and decolorization of treated palm oil mill effluent by oil palm fiber-immobilized trametes hirsuta strain AK 04. Water, Air, and Soil Pollution, 226: 345.

30. Hussin, M. H., Pohan, N. A., Garba, Z. N., Kassim, M. J., Rahim, A. A., Brosse, N. and Haafiz, M. K. M. (2016). Physicochemical of microcrystalline cellulose from oil palm fronds as potential methylene blue adsorbents. International Journal of Biological Macromolecules, 92: 11-19.

31. Wong, K. T., Eu, N. C., Ibrahim, S., Kim, H., Yoon, Y. and Jang, M. (2015). Recyclable magnetite-loaded palm shell-waste based activated carbon for the effective removal of methylene blue from aqueous solution. Journal of Cleaner Production, 115: 337-342.

32. Setiabudi, H. D., Jusoh, R., Suhaimi, S. F. R. M. and Masrur, S. F. (2015). Adsorption of methylene blue onto oil palm (Elaeis guineensis) leaves: Process optimization, isotherm, kinetics and thermodynamic studies. Journal of the Taiwan Institute of Chemical Engineers, 63: 363-370.

33. Zaini, M. A. A., Meng, T. W., Kamaruddin, M. J., Setapar, S. H. M. and Yunus, M. A. C. (2014). Microwaveinduced zinc chloride activated palm kernel shell for dye removal. Sains Malaysiana, 43(9): 1421-1428.

34. Acquah, C., Sie Yon, L., Tuah, Z., Ling Ngee, N. and Danquah, M. K. (2016). Synthesis and performance analysis of oil palm ash (OPA) based adsorbent as a palm oil bleaching material. Journal of Cleaner Production, 139: 1098-1104.

35. Khanday, W. A., Asif, M. and Hameed, B. H. (2016). Cross-linked beads of activated oil palm ash zeolite/chitosan composite as a bio-adsorbent for the removal of methylene blue and acid blue 29 dyes. International Journal of Biological Macromolecules, 95: 895-902.

36. Shaarani, F. W. and Hameed, B. H. (2011). Ammonia-modified activated carbon for the adsorption of 2,4dichlorophenol. Chemical Engineering Journal, 169(1-3): 180-185.

37. Salman, J. M. and Hameed, B. H. (2010). Effect of preparation conditions of oil palm fronds activated carbon on adsorption of bentazon from aqueous solutions. Journal of Hazardous Materials, 175(1-3), 133-137. 
38. Hamad, B. K., Noor, A. M., Afida, A. R. and Mohd Asri, M. N. (2010). High removal of 4-chloroguaiacol by high surface area of oil palm shell-activated carbon activated with $\mathrm{NaOH}$ from aqueous solution. Desalination, 257(1-3): 1-7.

39. Hamad, B. K., Noor, A. M. and Rahim, A. A. (2011). Removal of 4-chloro-2-methoxyphenol from aqueous solution by adsorption to oil palm shell activated carbon activated with $\mathrm{K}_{2} \mathrm{CO}_{3}$. Journal of Physical Science, 22(1): 39-55.

40. Nasir, M. A. M. and Saleh, S. H. (2016). Characterization of hemicelluloses from oil palm empty fruit bunches obtained by alkaline extraction and ethanol precipitation. Malaysian Journal of Analytical Sciences, 20(4), 849-855.

41. Yavari, S., Malakahmad, A., Sapari, N. B. and Yavari, S. (2016). Sorption-desorption mechanisms of imazapic and imazapyr herbicides on biochars produced from agricultural wastes. Journal of Environmental Chemical Engineering, 4(4): 3981-3989.

42. Salman, J. M., Abid, F. M. and Muhammed, A. A. (2012). Batch study for pesticide glyphosate adsorption onto palm oil fronds activated carbon. Asian Journal of Chemistry, 24(12): 5646-5648.

43. Hameed, B. H., Tan, I. A. W. and Ahmad, A. L. (2009). Preparation of oil palm empty fruit bunch-based activated carbon for removal of 2,4,6-trichlorophenol: Optimization using response surface methodology. Journal of Hazardous Materials, 164(2-3): 1316-1324.

44. Salman, J. M., Njoku, V. O. and Hameed, B. H. (2011). Batch and fixed-bed adsorption of 2,4dichlorophenoxyacetic acid onto oil palm frond activated carbon. Chemical Engineering Journal, 174(1): 33-40.

45. Tan, I., Lim, L. and Lim, K. (2013). Removal of atrazine from aqueous solutions using $\mathrm{HNO}_{3}$ treated oil palm shell-based adsorbent. Unimas e-Journal of Civil Engineering, 4(3): 17-22.

46. Salamatinia, B., Kamaruddin, A. H. and Abdullah, A. Z. (2008). Modeling of the continuous copper and zinc removal by sorption onto sodium hydroxide-modified oil palm frond in a fixed-bed column. Chemical Engineering Journal, 145(2): 259-266.

47. Wahi, R., Ngaini, Z. and Jok, V. (2009). Removal of mercury, lead and copper from aqueous solution by activated carbon of palm oil empty fruit bunch. World Applied Sciences Journal, 5: 84-91.

48. Rehman, M. A., Yusoff, I., Ahmmad, R. and Alias, Y. (2015). Arsenic Adsorption using palm oil waste clinker sand biotechnology: an experimental and optimization approach. Water, Air, and Soil Pollution, 226(5): 149.

49. Daneshfozoun, S., Abdullah, B. and Abdullah, M. A. (2016). The effects of oil palm empty fruit bunch sorbent sizes on plumbum (II) ion sorption. Advanced Materials Research, 1133: 542-546.

50. Daneshfozoun, S., Redza, R., Vo, D.-V. N., Ramli, N. M., Abdullah, M. A. and Abdullah, B. (2017). Adsorption kinetics of $\mathrm{Pb}(\mathrm{II})$ ions from aqueous solution using modified magnetic nano-composite of OPEFB. Indian Journal of Science and Technology, 10(11), 1-5.

51. Lua, A. C. and Jia, Q. (2009). Adsorption of phenol by oil-palm-shell activated carbons in a fixed bed. Chemical Engineering Journal, 150(2-3): 455-461.

52. Alam, M. Z., Muyibi, S. A., Mansor, M. F. and Wahid, R. (2007). Activated carbons derived from oil palm empty-fruit bunches: Application to environmental problems. Journal of Environmental Sciences, 19(1): 103-108.

53. AL-Aoh, H. A., Maah, M. J., Ahmad, A. A., and Abas, M. R. (2012). Adsorption of 4-nitrophenol on palm oil fuel ash activated by amino silane coupling agent. Desalination and Water Treatment, 40(1-3), 159-167. 